\title{
DE
}

DE GRUYTER

OPEN

Arch. Min. Sci., Vol. 61 (2016), No 4, p. 729-748

Electronic version (in color) of this paper is available: http://mining.archives.pl

DOI 10.1515/amsc-2016-0050

JOANNA KOMOREK*

\section{INTERNAL STRUCTURE OF VITRINITE AND SPORINITE IN THE VIEW OF MICRO-FTIR SPECTROSCOPY USING THE EXAMPLE OF COAL FROM THE SEAM 405 OF THE UPPER-SILESIAN COAL BASIN (USCB)}

\section{STRUKTURA WEWNĘTRZNA WITRYNITU I SPORYNITU W ŚWIETLE BADAŃ MIKRO-FTIR NA PRZYKLADZIE WĘGLA Z POKLADU 405 Z GÓRNOŚLĄSKIEGO ZAGLĘBIA WĘGLOWEGO (GZW)}

The aim of the study was to compare the internal structure of vitrinite and sporinite obtained from coal from the seam 405 . The examinations were performed with the use of infrared spectroscopy in the micro-area (micro-FTIR).

Studies have shown that vitrinite is characterized by lower content of aliphatic components and greater content of aromatic components than sporinite. Sporinite is characterized by longer and less branched aliphatic chains than vitrinite.

It was found that vitrinite internal structure is characterized by a greater relative content of aromatic than aliphatic components. The degree of condensation of aromatic rings in structure of vitrinite increases, when the coal rank rises. Studies have shown that the transformation of the vitrinite internal structure towards a structure characterized by a greater degree condensation of aromatic components proceeds at the cost of restructuring the aliphatic groups and is related to the restructuring of the aromatic systems.

The structure of sporinite is characterized by a greater participation of aliphatic bonds as compared to aromatic bonds. The relative content of the aliphatic components decreases together with increase of aromatic hydrogen functional group $\mathrm{CH}_{\mathrm{ar}}$ content in the internal structure of sporinite when the coal rank rises. The aliphatic bonds in the sporinite are subject to restructuring. The aliphatic chains are getting increasingly shorter.

Keywords: vitrinite, sporinite, internal structure of vitrinite and sporinite, micro-FTIR

Celem przeprowadzonych badań było porównanie struktury wewnętrznej witrynitu i sporynitu z wegla z pokładu 405 z GZW. Badania przeprowadzono metodą analizy spektralnej w podczerwieni w mikroobszarze (mikro-FTIR).

Badania wykazały, że witrynit charakteryzuje się mniejszym udziałem składników alifatycznych i większym udziałem składników aromatycznych niż sporynit. Sporynit charakteryzuje dłuższymi słabiej rozgałęzionymi łańcuchami alifatycznymi niż witrynit. Stwierdzono, że struktura witrynitu charakteryzuje

* INSTYTUt GEOlOGil STOSOWANEJ, POLITECHNIKA ŚLĄSKA, 44-100 GLIWICE, Ul. AKADEMICKA 2, POLAND. E-mail: joanna.komorek@polsl.pl 
się większym względnym udziałem składników aromatycznych niż alifatycznych. Wraz ze wzrostem stopnia uwęglenia rośnie stopień kondensacji pierścieni aromatycznych w witrynicie. Badania wykazały, że przemiany struktury witrynitu w kierunku struktury charakteryzującej się większym stopniem kondensacji składników aromatycznych odbywają się kosztem przebudowy składników alifatycznych oraz związane są też z przebudową układów aromatycznych.

Struktura sporynitu z charakteryzuje się większym udziałem wiązań alifatycznych niż aromatycznych. Wraz ze wzrostem stopnia uwęglenia w strukturze wewnętrznej sporynitu maleje udział wiązań alifatycznych przy jednoczesnym wzroście zawartości wiązań aromatycznych $\mathrm{CH}_{\mathrm{ar}}$. Wiązania alifatyczne w sporynicie ulegają przebudowie. Łańcuchy wiązań alifatycznych stają się coraz krótsze.

Słowa kluczowe: witrynit, sporynit, struktura wewnętrzna witrynitu i sporynitu, mikro-FTIR

\section{Introduction}

Both the chemical and technological, as well as physical properties resulting from the ordering of the internal structure of coal vary with the coal rank with a certain regularity. (Gabzdyl, 1987; Probierz, 1989). The structure of coal influences the course of many processes such as carbonization, oxidation and gasification. The knowledge of the internal structure of coal facilitates the understanding and control over these processes (Lu et al., 2001). Many different research techniques are used for the analysis of coal structure. One of the most commonly used is the infrared spectroscopy which uses the Fourier transformation (FTIR). Traditional FTIR techniques allow for the testing of channel samples of coal or of concentrate samples of individual maceral groups (Chen et al., 2012, 2013). In recent years, however, the micro-FTIR analysis in which the infrared spectrometer is linked to an optical microscope, allowing for micro-area analyses, is more and more common in the petrographic components research (Chen et al., 2012, 2013; Guo \& Bustin, 1998; 1998a; Mastalerz \& Bustin, 1995, 1996). The analyses of the Polish bituminous coal using the micro-FTIR method are carried out since recently (Hacura et al., 2003; Komorek, 2013, 2013a; Morga, 2010, 2010a, 2011). The FTIR method allows to determine the functional groups in individual petrographic components of coal and their derivatives (Guo \& Bustin, 1998, 1998a; Guo et al., 1996; Hacura et al., 2003; Iglesias et al., 1995; Komorek, 2013, 2013a; Mastalerz \& Bustin, 1995; 1996, 1997; Morga, 2010, 2010a, 2011).

The spectroscopic analyses of coal have indicated that along with the increase of coalification, the content of hydroxyl groups and aliphatic groups decreases. In contrast, the aromatic hydrogen content and degree of condensation of aromatic structures is increased (Ibara et al., 1996; Jasieńko, 1995; Lis et al., 2005; Mastalerz, 1996; Mastalerz \& Bustin, 1995).

Guo and Bustin found that the micro-FTIR spectra of macerals of the liptinite group are characterized by intensive absorption from aliphatic groups and a high value of the $\mathrm{CH}_{2} / \mathrm{CH}_{3}$ intensity ratio, which means that liptinite contains relatively large amounts of aliphatic components. The aliphatic components of liptinite are long chained and less branched. Liptinite contain relatively less aromatic components in relation to other macerals.

Differences were also observed within the liptinite group in the ratio of aliphatic and aromatic components. Among all the macerals of the liptinite group, sporinite is characterized by the shortest and most branched aliphatic chains (Guo \& Bustin, 1998).

It was found that changes in internal structure of sporinite undergo with the increase of degree of its thermal maturation. This is caused by the formation of multi-ring aromatic units from isolated aromatic units. The size of these polyaromatic units increases with coal rank (Yule at al., 2000). 
A comparison of liptinite, vitrinite and inertinite structures from iso-rank coal samples proved that liptinite shows the highest value of the $\mathrm{CH}_{2} / \mathrm{CH}_{3}$ ratio, which characterizes the length of the aliphatic chains. Inertinite is characterized by the highest aromaticity, while vitrinite exhibits properties intermediate between liptinite and inertinite (Chen et al., 2012).

Micro-FTIR analyses of fusinite and semifusinite have demonstrated that fusinite - as compared to semifusinite obtained from the same coal - exhibits higher aromaticity and condensation of the structure (Morga, 2010, 2010a, 2011).

The aim of the study was to compare the internal structure of vitrinite and sporinite obtained from coal samples from the seam 405, based on the content of the aliphatic and aromatic bonds, using micro-FTIR spectroscopy.

\section{Sampling and methods}

The Upper-Silesian Coal Basin is one of the most significant Carboniferous basins of Europe. It stretches through the Silesia-Cracow Upland, at an area of approximately $6100 \mathrm{~km}^{2}$, out of which, $1600 \mathrm{~km}^{2}$ is located in the Czech Republic (Ostrava-Karviná Basin). Besides the Ruhr district and the Donets Basin it is the largest in Europe (Gabzdyl, 1999; Probierz et al., 2012). The Upper Silesian Basin has been formed at the foreland of the Eastern Sudetes foredeep in palaeogeographic conditions similar to the ones of the north-western part of Germany, Belgium, and Wales. The formation of the Upper-Silesian Coal Basin is related to the Variscan geotectonic epoch (Probierz et al., 2012). The Upper-Silesian Coal Basin is located in the area of occurrence of coal-bearing formations of the Carboniferous covering the central and north-western part of Europe. It is located in the south-eastern part of this area, constituting one of the most significant coal basins in this part of the European Union (Probierz et al., 2012). It is triangular in shape, filled with coal-bearing formations of the upper-Carboniferous (Fig. 1). The western boundary runs from SSW to NNE - from Novy Jičin to the west of Ostrava, Rybnik and Gliwice and then turns east to Tarnowskie Góry. Its eastern boundary runs from NW to SE - from Tarnowskie Góry to the east of Dąbrowa Górnicza and then between Olkusz and Chrzanów, through Tenczynek in the direction of Myślenice. The southern boundary is by convention denoted by the overthrust of the Carpathians, which runs from Frýdek-Místek through Cieszyn, Bielsko-Biała to Wadowice (Gabzdyl, 1999). The basin exhibits a wide variety of tectonic structures which may be assigned to a few regional directions. A fold tectonic zone is located along the western boundary of the basin in line with the SSW-NNE direction ("Moravian-Silesian"). The predominating part of the basin is taken up by a disjunctive tectonic zone, the general structure of which is in line with the W-E direction. At the NE edge of the Upper-Silesian Coal Basin there is a zone of fold-block and fold tectonics (Kotas, 1972, 1985).

The study was based on 9 channel coal samples from the seam 405 Westphalian A mudstone series and included in the Załęże beds in line with the stratigraphic division of the Carboniferous period in line with the National Geological Institute or to the Ruda beds in line with the T. Bocheński and S. Doktorowicz Hrebnicki division (Probierz et al., 2012). This seam has been selected for the study as it is deemed to be the marker bed. It is characterized by a fixed thickness and relatively large seam thickness $(2-6 \mathrm{~m})$. It is the most recognized out of all the seams in the group in most of the areas of the USCB (Porzycki, 1972). The selection of the seam 405 allowed to obtain samples from coal mines located in various regions of the Upper Silesian Coal Basin, selected so as to represent the largest possible range of coalification. In the selection of 
samples characterized by the highest rank, it was ensured that sporinite could be distinguished against the background of the basic colodetrinite mass. Samples for the fold tectonics zone have been obtained from the "Jankowice" coal mine (samples 1,2). Samples for the disjunctive zone have been obtained from the "Brzeszcze" coal mine (sample 3). The remaining samples have been obtained from the zone of mixed tectonics styles (samples 4-9). The list and the locations of the samples have been presented in Table 1 and Fig. 1.

The channel samples were subjected to microscopic examinations and spectral infrared analysis in micro-region (micro-FTIR).

For the purposes of the microscopic analysis, the samples were diminished and crushed, to grain-size $<1 \mathrm{~mm}$. They were used for preparation of polished grain mounts for microscopic examination in reflected light. Mean reflecance of vitrinite $\left(R_{v}\right)$ and sporinite $\left(R_{l}\right)$ was determined according to the PN-ISO 7404-5: 2002 standard. To determine the petrographic composition of the tested coal samples, analysis of the maceral composition was performed (PN-ISO 7404-3: 2001). Petrographic composition and reflectance measurement were done with use of Zeiss microscope Axioscope, in immersion oil $\left(n_{0}=1.518\right.$ at $\left.23^{\circ} \mathrm{C}\right)$ and light wave length $\lambda=546 \mathrm{~nm}$.

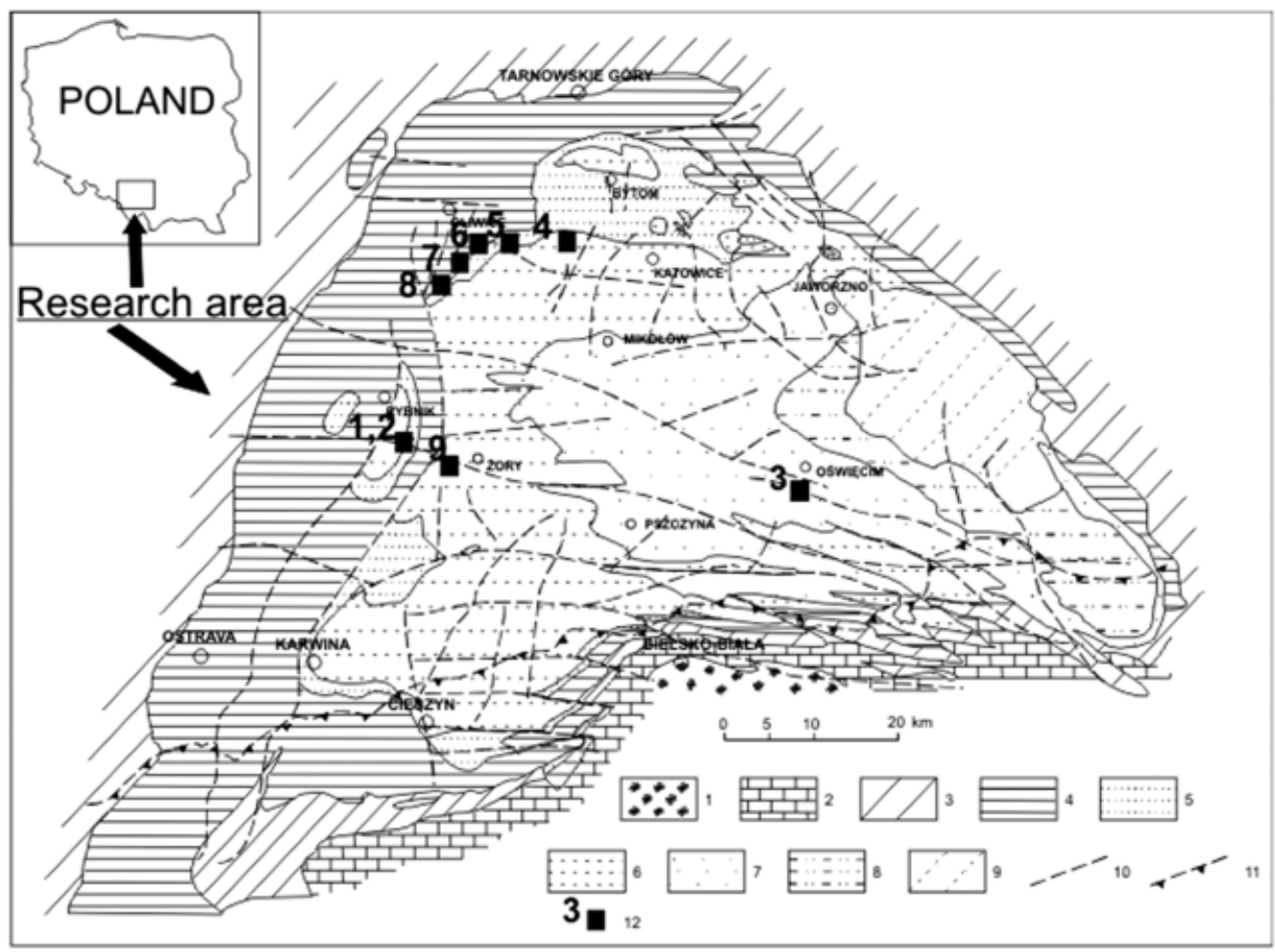

Fig. 1. The sampling location on the background of geological sketch of Upper Silesian Coal Basin Symbols: 1 - Devonian metamorphic rocks, 2 - Devonian carbonate and clastic marine sediments, 3 - diastrophic marine sediments; 4 - Paralic Series (Brzeżne beds), 5 - Upper Silesian Sandstone Series

(Saddle and Ruda s.s.beds), 6 - Mudstone Series (Ruda and Orzesze beds), 7 - Łaziska beds, 8 - Libiąż Layers, 9 - Kwaczała Arkose, 10 - main faults, 11 - Carpathian overthrust, 12-sampling location - sample number as in Table 1(according to Gabzdyl, 1999, modified) 
The list of examined samples

\begin{tabular}{|c|l|c|}
\hline \hline Sample & \multicolumn{1}{|c|}{ Location } & Seam \\
\hline 1 & „Jankowice” coal mine & $405 / 1$ \\
\hline 2 & „Jankowice” coal mine & $405 / 2$ \\
\hline 3 & „Brzeszcze” coal mine & $405 / 1$ \\
\hline 4 & „Halemba-Wirek” coal mine - part „Halemba” & $405 / 1$ \\
\hline 5 & „Sośnica-Makoszowy” coal mine -part „Makoszowy” & $405 / 2$ \\
\hline 6 & „Sośnica-Makoszowy” coal mine - part „Sośnica” & $405 / 2$ \\
\hline 7 & „Knurów-Szczygłowice” coal mine - part „Knurów” & $405 / 3$ \\
\hline 8 & „Knurów-Szczygłowice” coal mine - part „Szczygłowice” & $405 / 3$ \\
\hline 9 & „Borynia-Zofiówka” coal mine - part „Borynia” & $405 / 1$ \\
\hline
\end{tabular}

Micro-FTIR analysis has been performed on individual grains of vitrinite (colotelinite) and liptinite (sporinite). Polished grain mounts made using a standard method were used. The spectra were registered for each component in 10-15 measurement points. The measurements have been made using the Bio-Rad FTS-6000 spectrometer equipped with a Bio-Rad UMA-500 microscope. All micro-FTIR measurements were performed in reflectance mode. Spectra were registered in the range of $4500-700 \mathrm{~cm}^{-1}$ with a resolution of $4 \mathrm{~cm}^{-1}$. The spectra were generated by collecting 512 scans. All recorded reflectance spectra were transformed using the Fourier and Kramer Krönig procedures provided by BioRad.

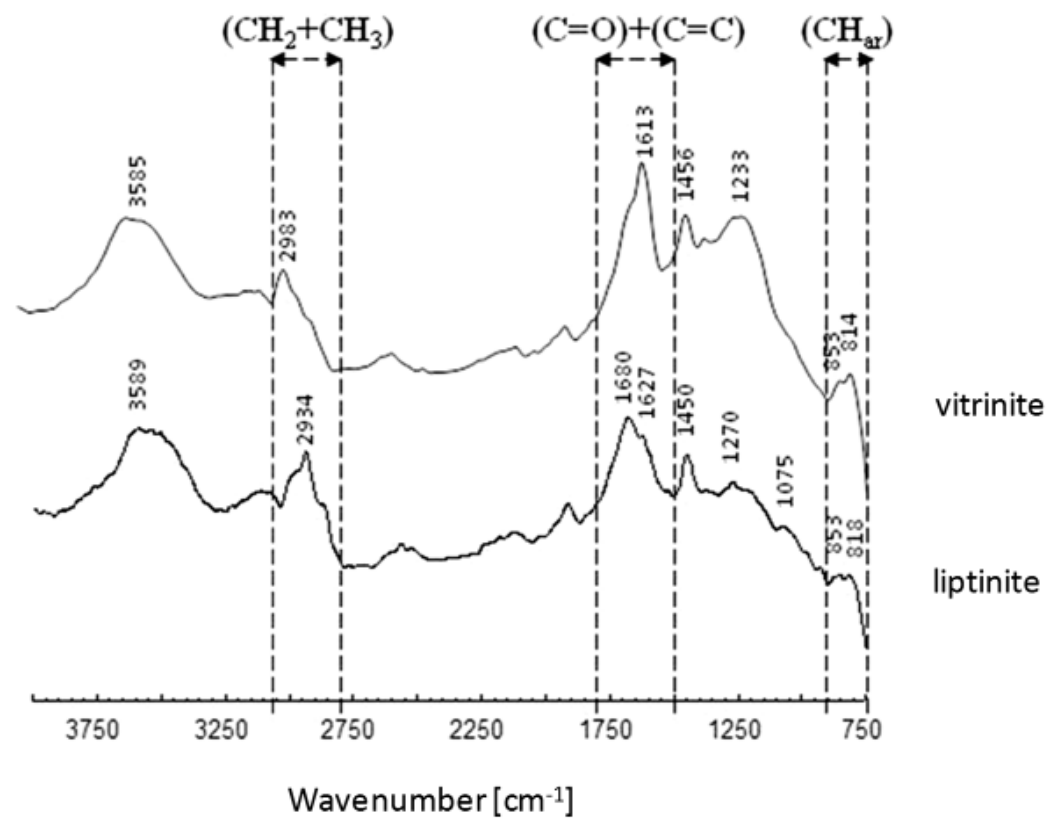

Fig. 2. Example of micro-FTIR spectra (sample 2) 
To characterize the chemical structure of vitrinite and sporinite, from FTIR spectra were taken into account following absorption bands in ranges (Fig. 2):

- 3030-2800 $\mathrm{cm}^{-1}-$ aliphatic $\left(\mathrm{CH}_{2}+\mathrm{CH}_{3}\right)$ stretching vibration,

- $1800-1650 \mathrm{~cm}^{-1}-$ aromatic carbonyl/carboxyl $\mathrm{C}=\mathrm{O}$ stretching vibration,

- $1650-1500 \mathrm{~cm}^{-1}$ - aromatic $\mathrm{C}=\mathrm{C}$ ring stretching vibration,

- 900-750 $\mathrm{cm}^{-1}$ - aromatic $\mathrm{CH}_{\mathrm{ar}}$ out of plane deformation.

The GRAM/32 program was used for spectral deconvolution curve fitting and determination of peak integration area in the range of aliphatic stretching $\mathrm{CH}_{2}+\mathrm{CH}_{3}$ signal around 3030-2800 $\mathrm{cm}^{-1}$. Bands corresponding to asymmetric stretching vibrations of the aliphatic $\mathrm{CH}_{2}$ groups were separated with a maximum at the wave number of $2920 \mathrm{~cm}^{-1}$ and of the $\mathrm{CH}_{3}$ with a maximum wave number of approximately $2960 \mathrm{~cm}^{-1}$. The aliphatic region was baseline-linearized. Position and number of bands were established from second derivate of the spectrum. A combination Gaussian-Lorentzian function was used for peak shapes. The goodness of fit was checked using the parameter (chi-squared) $\chi^{2}$ (Fig. 3).

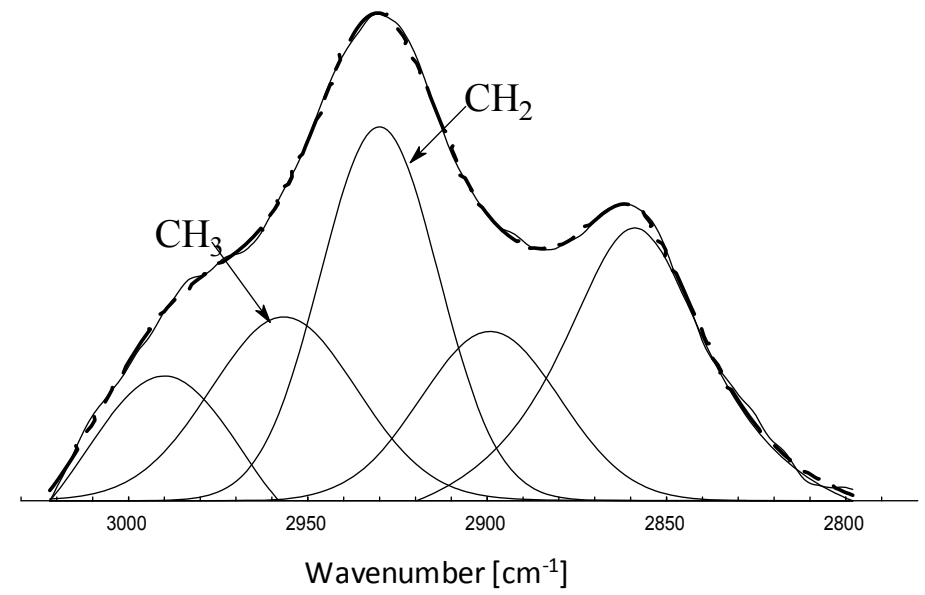

Fig. 3. The example of deconvolution of micro-FTIR spectrum in the range $3030-2800 \mathrm{~cm}^{1}$ (sporinite, sample 2)

The chemical characteristics of the vitrinite and sporinite structures were obtained by determining the intensity ratios of the individual bands. The works by Guo and Bustin, 1998; Hacura, et al., 2003; Mastalerz and Bustin, 1993; 1995; 1996; 1997 served as a model.

The integrations area and not the intensity (height) of individual peaks has been considered in the calculation of the individual ratios.

To compare the relative content of aliphatic and aromatic components in vitrinite and sporinite, three parameters describing the intensity ratios of the following spectral bands have been proposed:

$$
I_{1}=\frac{\left(\mathrm{CH}_{2}+\mathrm{CH}_{3}\right)}{\left(\mathrm{CH}_{2}+\mathrm{CH}_{3}\right)+(\mathrm{C}=\mathrm{C})+\mathrm{CH}_{\mathrm{ar}}}
$$


specifying the relative content of the aliphatic components in the vitrinite and sporinite structures,

$$
I_{2}=\frac{(\mathrm{C}=\mathrm{C})}{\left(\mathrm{CH}_{2}+\mathrm{CH}_{3}\right)+(\mathrm{C}=\mathrm{C})+\mathrm{CH}_{\mathrm{ar}}}
$$

specifying the relative content of the aromatic components of the $\mathrm{C}=\mathrm{C}$ groups (aromatic rings) in the vitrinite and sporinite structures,

$$
I_{3}=\frac{\mathrm{CH}_{\mathrm{ar}}}{\left(\mathrm{CH}_{2}+\mathrm{CH}_{3}\right)+(\mathrm{C}=\mathrm{C})+\mathrm{CH}_{\mathrm{ar}}}
$$

specifying the relative content of aromatic hydrogen functional groups in the vitrinite and sporinite structures.

The following ratio is the measure of degree of condensation of the aromatic rings (Guo \& Bustin, 1998):

$$
I_{4}=\frac{\mathrm{CH}_{\mathrm{ar}}}{(\mathrm{C}=\mathrm{C})}
$$

The ratios characterizing the length and degree of branching of aliphatic side-chains and the relative content of the $\mathrm{CH}_{2}$ and $\mathrm{CH}_{3}$ aliphatic groups have also been specified (Guo \& Bustin, 1998; Mastalerz \& Bustin, 1993, 1995, 1996, 1997):

$$
\begin{gathered}
I_{5}=\frac{\mathrm{CH}_{2}}{\mathrm{CH}_{3}} \\
I_{6}=\frac{\mathrm{CH}_{2}}{\left(\mathrm{CH}_{2}+\mathrm{CH}_{3}\right)} \\
I_{7}=\frac{\mathrm{CH}_{3}}{\left(\mathrm{CH}_{2}+\mathrm{CH}_{3}\right)}
\end{gathered}
$$

The results presented in this work constitute the continuation of earlier chemical and structural studies of vitrinite and liptinite maceral groups. The previously analyzed relations between the coal rank and the values of the $I_{1}-I_{4}$ absorbance ratios presented in the work Komorek, 2013a have been supplemented with relations representing the $I_{5}-I_{7}$ absorbance ratios which characterize the aliphatic bonds in vitrinite and sporinite.

\section{Research results}

\subsection{Results of microscopic analyses}

It was found that the coal samples from the coal seam 405 are characterized by a mean vitrinite reflectance from $R_{v}=0.70 \%$ (sample 1) to $R_{v}=1.25 \%$ (sample 9) (Table 2). Therefore examined coal samples represent medium - rank orthobituminous (C) (samples 1-7) and metabituminous (B) (sample 8-9) coal (ECE-Geneva 1994). 
The content of $\left(V^{m m f}\right)$ vitrinite in the analyzed coal samples varies in the range between $51 \%$ and $79 \%$ (Table 2 ). Among the vitrinite group macerals, mostly colodetrinite and colotelinite occur, while telinite and corpogelinite were observed less frequently. The content of macerals of the vitrinite group $\left(V^{m m f}\right)$ exceeds $60 \%$ in most of the samples. Most of the analyzed samples may thus be considered as high-vitrinite (ECE Genewa 1994). Samples 5, 6 and 7 are an exception - their vitrinite contents are $51 \%, 56 \%$ and $59 \%$, respectively.

TABLE 2

Rank and petrographic composition of the examined coal samples (Komorek, 2013a)

\begin{tabular}{|c|c|c|c|c|c|c|c|c|}
\hline \hline Próbka & $\boldsymbol{R}_{\boldsymbol{v}}[\mathbf{\%}]$ & $\boldsymbol{s}_{\boldsymbol{v}}[\mathbf{\%}]$ & $\boldsymbol{R}_{\boldsymbol{I}}[\mathbf{\%}]$ & $\boldsymbol{s}_{\boldsymbol{I}}[\mathbf{\%}]$ & $\boldsymbol{V}^{\mathbf{m m f}}[\mathbf{\%}]$ & $\boldsymbol{L}^{\mathbf{m m f}}[\mathbf{\%}]$ & $\boldsymbol{I}^{\mathbf{m m f}}[\mathbf{\%}]$ & $\boldsymbol{S M}[\mathbf{\%}]$ \\
\hline 1 & 0.70 & 0.04 & 0,18 & 0,04 & 79 & 13 & 8 & 2 \\
\hline 2 & 0.83 & 0.04 & 0,20 & 0,05 & 75 & 13 & 12 & 2 \\
\hline 3 & 0.87 & 0.04 & 0,21 & 0,04 & 65 & 14 & 21 & 3 \\
\hline 4 & 0.87 & 0.04 & 0,23 & 0,03 & 62 & 9 & 29 & 1 \\
\hline 5 & 0.92 & 0.05 & 0,22 & 0,03 & 51 & 13 & 36 & 3 \\
\hline 6 & 0.92 & 0.04 & 0,31 & 0,03 & 56 & 10 & 34 & 1 \\
\hline 7 & 0.96 & 0.04 & 0,32 & 0,03 & 59 & 12 & 29 & 2 \\
\hline 8 & 1.03 & 0.04 & 0,40 & 0,05 & 61 & 8 & 32 & 2 \\
\hline 9 & 1.25 & 0.06 & 0,95 & 0,05 & 69 & 5 & 26 & 1 \\
\hline
\end{tabular}

The content of macerals of the liptinite group $\left(L^{m m f}\right)$ in the analyzed samples varies in the range between $5 \%$ and $14 \%$ (Table 2 ). The most commonly observed maceral of the liptinite group was the sporinite represented both by micro- and megaspores. Cutinite resinite and liptodetrinite were observed less frequently. The reflectance of sporinite varies in the range from $R_{l}=0.18 \%$ (sample 1) to $R_{l}=0.95 \%$ (sample 9, Table 2). The relationship between vitrinite and sporinite reflectance in the analyzed coal samples has been presented in the view of the dependence exhibited by K. Probierz 1989 (Fig. 4). Based on the microscopic observations, it was found that sporinite from nearly all the coal samples (samples 1-8) exhibited clear orange fluorescence at the $R_{v}$ vitrinite reflexivity value between $0.70 \%$ and $1.03 \%$. The highest intensity of the fluorescence has been observed in samples $1-4$, characterized by the lowest reflectance values $\left(R_{v}<0.90 \%\right)$. Sporinite from sample $9\left(R_{v}=1.25 \%\right)$ has exhibited nearly no fluorescence (determined qualitatively) or fluoresced very weakly, similarly to other sporinites coming from the SW part of the Upper Silesian Coal Basin, described by Probierz (Probierz, 1989; Komorek et al., 2010; Probierz et al., 2012; Adamczyk et al., 2014). The loss of fluorescence in this sample is related to the process of sporinite vitrinization. Sporinite in the analyzed sample is, however, characterized by reflectance value lower than that of vitrinite (Table 2). The equalization of sporinite and vitrinite reflectance values only occurs in the vitrinite reflectance range from $1.40 \%$ to $1.60 \%$ (Pozzi \& Probierz, 1986; Probierz, 1989). The qualitative observations of the fluorescence of sporinite from the seam 405 confirm the observations of K. Probierz made for the coal coming from the SW part of the Upper Silesian Coal Basin.

The inertinite content $\left(I^{m m f}\right.$ ) varies in a wide range from $8 \%$ to $36 \%$ (Table 2 ). The inertinite group is represented by inertodetrinite, semifusinite and macrinite. Micrinite, fusinite and funginite, are observed rarely.

The mineral matter content in the examined samples is low and varies in the range of $1 \%-$ $3 \%$ (Table 2). The mineral matter is mostly represented by iron sulphides and carbonates. Clay minerals and polymineral substance were observed rarely. 


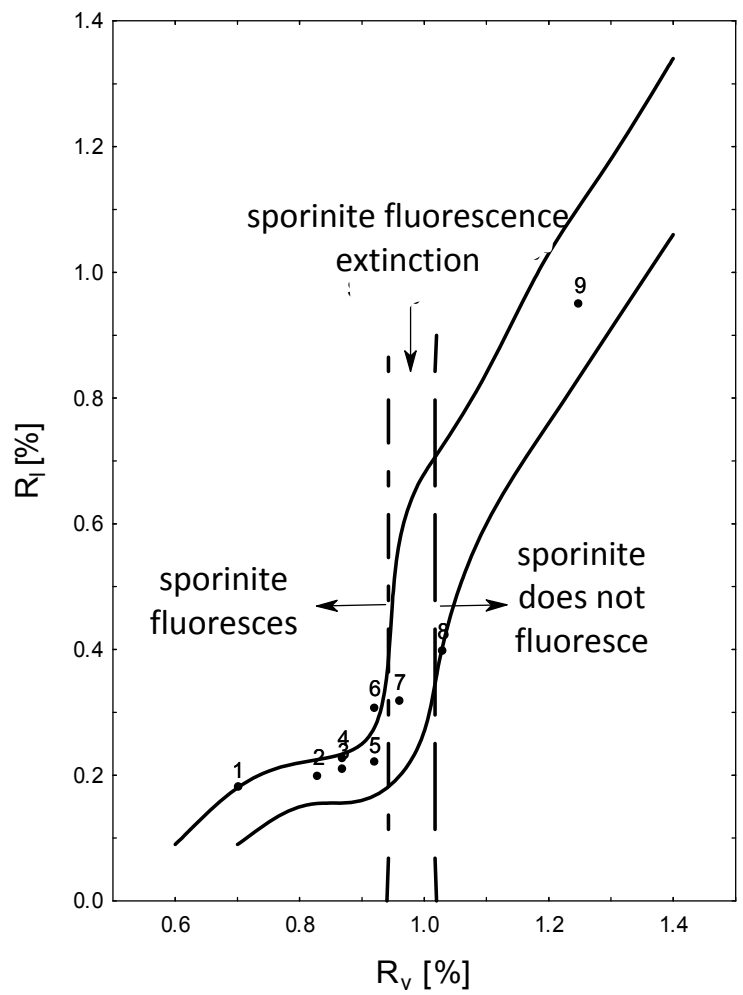

Fig. 4. The relationship between sporinite and vitrinite reflectance in the analyzed coal samples presented in the view of the dependence exhibited by K. Probierz (1989)

\subsection{Results of the micro-FTIR analysis}

In the micro-FTIR spectra of vitrinite a peak associated with $\mathrm{OH}$ groups vibrations is visible with a maximum of approximately $3553 \mathrm{~cm}^{-1}$. The band in the range of $3120-3030 \mathrm{~cm}^{-1}$, related to the stretching vibrations of $\mathrm{CH}_{\mathrm{ar}}$ aromatic groups (maximum of approximately $3074 \mathrm{~cm}^{-1}$ ), is weakly distinguishable, and not visible in some of the samples. In the $3030-2800 \mathrm{~cm}^{-1}$ wave number range, an intensive aliphatic absorption $\left(\mathrm{CH}_{2}+\mathrm{CH}_{3}\right)$ is visible, with a maximum at a wave number of approximately $2982 \mathrm{~cm}^{-1}$. After the deconvolution, the band associating with asymmetric stretching vibrations of the $\mathrm{CH}_{3}$ aliphatic groups exhibits a maximum in the range between 2978 and $2956 \mathrm{~cm}^{-1}$. The band related to the asymmetric stretching vibrations of the $\mathrm{CH}_{2}$ aliphatic groups exhibits a maximum in the range from 2930 to $2922 \mathrm{~cm}^{-1}$ in the analyzed samples. Significant intensity is also characteristic to bands from the range of $1800-1500 \mathrm{~cm}^{-1}$, which are related to the stretching vibrations of the $\mathrm{C}=\mathrm{O}$ groups and the $\mathrm{C}=\mathrm{C}$ aromatic rings. In vitrinite spectra, these bands combine in such a way that in their characteristic spectral range it is only possible to distinguish one clear maximum at a wave number of about $1607 \mathrm{~cm}^{-1}$. In the vitrinite spectra, clear maximum also occur at a wave number of approximately $1445 \mathrm{~cm}^{-1}$. These maxima are related to deformation vibrations of aliphatic groups $\left(\mathrm{CH}_{2}+\mathrm{CH}_{3}\right)$. Weak and 
variable intensity is characteristic to bands of the oxygen functional groups with a maximum at wave numbers of approximately $1260 \mathrm{~cm}^{-1}, 1210 \mathrm{~cm}^{-1}$ and $1035 \mathrm{~cm}^{-1}$. In the analyzed spectra, the band of the $900-750 \mathrm{~cm}^{-1}$ range is easily distinguishable - this band is related to out of plane deformation vibrations of $\mathrm{CH}_{\mathrm{ar}}$ aromatic groups. In this range, two peaks are most commonly visible: at the wave numbers of approximately $857 \mathrm{~cm}^{-1}$ and $811 \mathrm{~cm}^{-1}$.

In the micro-FTIR spectra of sporinite a peak associated with $\mathrm{OH}$ groups vibrations is visible with a maximum of approximately $3590 \mathrm{~cm}^{-1}$. This band is characterized by a greater intensity than in the vitrinite spectrum. The band in the range of $3120-3030 \mathrm{~cm}^{-1}$, related to the stretching vibrations of $\mathrm{CH}_{\mathrm{ar}}$ aromatic groups with a maximum of approximately $3074 \mathrm{~cm}^{-1}$, is (similarly as in vitrinite) weakly distinguishable, and not visible at all in some of the samples.

Micro-FTIR spectra of sporinite are characterized by strong aliphatic absorption $\left(\mathrm{CH}_{2}+\mathrm{CH}_{3}\right)$, at $3030-2800 \mathrm{~cm}^{-1}$ with a maximum at approximately $2933 \mathrm{~cm}^{-1}$. This band has greater intensity than in vitrinite spectra. After deconvolution, the band associated with asymmetric stretching vibrations of the $\mathrm{CH}_{3}$ aliphatic groups exhibits a maximum in the range between 2970 and $2954 \mathrm{~cm}^{-1}$. The band related to the asymmetric stretching vibrations of the $\mathrm{CH}_{2}$ groups exhibits a maximum in the range from 2929 to $2922 \mathrm{~cm}^{-1}$ in the analyzed samples. Significant intensity is also characteristic to bands from the range of $1800-1500 \mathrm{~cm}^{-1}$, in this range is possible to separate two peaks. First of the peaks is related to the stretching vibrations of the $\mathrm{C}=\mathrm{O}$ groups with a maximum at approximately $1678 \mathrm{~cm}^{-1}$, while the second one is related to the aromatic $\mathrm{C}=\mathrm{C}$ rings vibrations, with a maximum at approximately $1620 \mathrm{~cm}^{-1}$. In the liptinite spectra, clear maxima also occur at the wave number of approximately $1448 \mathrm{~cm}^{-1}$ - these are related to deformation vibrations of aliphatic groups $\left(\mathrm{CH}_{2}+\mathrm{CH}_{3}\right)$. As in the vitrinite spectra, the bands coming from oxygen functional groups are characterized by weak and variable intensity, with a maximum at wave numbers of approximately $1270 \mathrm{~cm}^{-1}, 1205 \mathrm{~cm}^{-1}, 1068-1031 \mathrm{~cm}^{-1}$. In the sporinite spectra, the band of the $900-750 \mathrm{~cm}^{-1}$ range is clearly distinguishable. This band is related to out of plane deformation of $\mathrm{CH}_{\mathrm{ar}}$ aromatic groups. In this range, as in the case of vitrinite, two peaks are most commonly visible: at the wave numbers of approximately $860 \mathrm{~cm}^{-1}$ and $811 \mathrm{~cm}^{-1}$.

The relative content of aliphatic and aromatic components in vitrinite and sporinite have been compared based on the value of the $I_{1}, I_{2}$ and $I_{3}$ intensity ratios.

The micro-FTIR analysis of vitrinite has indicated that the value of the ratio $I_{1}(1)$ varies in the range from 0.16 to 0.38 . In comparison to vitrinite, sporinite exhibits a greater value of this parameter. In case of liptinite, this ratio assumes a value from the range from 0.30 to 0.57 . This means that vitrinite is characterized by a lower content of aliphatic components than sporinite (Tables 3 and 4).

The $I_{2}$ ratio (2) determined for vitrinite assumes values from the range from 0.28 to 0.42 . That same ratio determined for sporinite is always lower than in vitrinite and assumes values from 0.19 to 0.30 .

The ratio $I_{3}(3)$ determined for vitrinite varies in the range from 0.32 to 0.48 . The same parameter determined for liptinite assumes lower values and varies in the range from 0.23 to 0.40 (Tables 3 and 4 ).

The values of the $I_{2}$ and $I_{3}$ ratios indicate that vitrinite is characterized by a greater content of aromatic components than liptinite. 
TABLE 3

The values of parameters characterizing chemical structure of vitrinite, determined based on the micro-FTIR spectra $\left(I_{1}-I_{4}\right.$ ratios - Komorek, 2013a)

\begin{tabular}{|c|c|c|c|c|c|c|c|}
\hline \hline Sample & $\boldsymbol{I}_{\mathbf{1}}$ & $\boldsymbol{I}_{\mathbf{2}}$ & $\boldsymbol{I}_{\mathbf{3}}$ & $\boldsymbol{I}_{\mathbf{4}}$ & $\boldsymbol{I}_{\mathbf{5}}$ & $\boldsymbol{I}_{\mathbf{6}}$ & $\boldsymbol{I}_{\mathbf{7}}$ \\
\hline \multirow{2}{*}{1} & 0,27 & 0,41 & 0,32 & 0,79 & 1,11 & 0,53 & 0,48 \\
& $(0,02)$ & $(0,01)$ & $(0,02)$ & $(0,05)$ & $(0,12)$ & $(0,03)$ & $(0,03)$ \\
\hline \multirow{2}{*}{2} & 0,22 & 0,42 & 0,36 & 0,85 & 0,98 & 0,49 & 0,51 \\
& $(0,01)$ & $(0,01)$ & $(0,01)$ & $(0,04)$ & $(0,20)$ & $(0,05)$ & $(0,05)$ \\
\hline \multirow{2}{*}{3} & 0,24 & 0,33 & 0,42 & 1,29 & 0,93 & 0,48 & 0,52 \\
& $(0,03)$ & $(0,02)$ & $(0,04)$ & $(0,16)$ & $(0,21)$ & $(0,06)$ & $(0,06)$ \\
\hline \multirow{2}{*}{4} & 0,34 & 0,31 & 0,36 & 1,17 & 0,82 & 0,45 & 0,56 \\
& $(0,01)$ & $(0,01)$ & $(0,01)$ & $(0,07)$ & $(0,17)$ & $(0,05)$ & $(0,05)$ \\
\hline \multirow{2}{*}{5} & 0,32 & 0,34 & 0,33 & 0,97 & 0,85 & 0,45 & 0,55 \\
& $(0,02)$ & $(0,01)$ & $(0,02)$ & $(0,05)$ & $(0,17)$ & $(0,06)$ & $(0,06)$ \\
\hline \multirow{2}{*}{6} & 0,21 & 0,40 & 0,39 & 0,99 & 1,10 & 0,52 & 0,48 \\
& $(0,03)$ & $(0,05)$ & $(0,02)$ & $(0,17)$ & $(0,24)$ & $(0,05)$ & $(0,05)$ \\
\hline \multirow{2}{*}{7} & 0,27 & 0,31 & 0,42 & 1,35 & 0,90 & 0,47 & 0,53 \\
& $(0,03)$ & $(0,01)$ & $(0,03)$ & $(0,10)$ & $(0,15)$ & $(0,04)$ & $(0,04)$ \\
\hline \multirow{2}{*}{8} & 0,38 & 0,28 & 0,33 & 1,21 & 0,92 & 0,47 & 0,53 \\
& $(0,03)$ & $(0,05)$ & $(0,05)$ & $(0,31)$ & $(0,18)$ & $(0,05)$ & $(0,05)$ \\
\hline \multirow{2}{*}{9} & 0,16 & 0,36 & 0,48 & 1,34 & 0,74 & 0,42 & 0,58 \\
& $(0,03)$ & $(0,02)$ & $(0,03)$ & $(0,15)$ & $(0,15)$ & $(0,05)$ & $(0,05)$ \\
\hline
\end{tabular}

Explanations: in brackets are standard deviation values of individual ratios

TABLE 4

The values of parameters characterizing chemical structure of liptinite, determined based on the micro-FTIR spectra $\left(I_{1}-I_{4}\right.$ ratios - Komorek, 2013a)

\begin{tabular}{|c|c|c|c|c|c|c|c|}
\hline \hline Sample & $\boldsymbol{I}_{\mathbf{1}}$ & $\boldsymbol{I}_{\mathbf{2}}$ & $\boldsymbol{I}_{\mathbf{3}}$ & $\boldsymbol{I}_{\mathbf{4}}$ & $\boldsymbol{I}_{\mathbf{5}}$ & $\boldsymbol{I}_{\mathbf{6}}$ & $\boldsymbol{I}_{\mathbf{7}}$ \\
\hline \multirow{2}{*}{1} & 0,51 & 0,26 & 0,23 & 0,89 & 1,61 & 0,61 & 0,39 \\
& $(0,02)$ & $(0,02)$ & $(0,02)$ & $(0,10)$ & $(0,30)$ & $(0,05)$ & $(0,05)$ \\
\hline \multirow{2}{*}{2} & 0,56 & 0,19 & 0,26 & 1,37 & 1,22 & 0,55 & 0,45 \\
& $(0,03)$ & $(0,01)$ & $(0,03)$ & $(0,17)$ & $(0,20)$ & $(0,04)$ & $(0,04)$ \\
\hline \multirow{2}{*}{3} & 0,48 & 0,23 & 0,28 & 1,26 & 1,46 & 0,59 & 0,41 \\
& $(0,04)$ & $(0,04)$ & $(0,04)$ & $(0,32)$ & $(0,24)$ & $(0,04)$ & $(0,04)$ \\
\hline \multirow{2}{*}{4} & 0,56 & 0,21 & 0,23 & 1,14 & 1,50 & 0,59 & 0,41 \\
& $(0,05)$ & $(0,02)$ & $(0,04)$ & $(0,22)$ & $(0,40)$ & $(0,06)$ & $(0,06)$ \\
\hline \multirow{2}{*}{5} & 0,54 & 0,22 & 0,23 & 1,03 & 1,70 & 0,62 & 0,38 \\
& $(0,05)$ & $(0,03)$ & $(0,05)$ & $(0,31)$ & $(0,52)$ & $(0,08)$ & $(0,08)$ \\
\hline \multirow{2}{*}{6} & 0,52 & 0,28 & 0,30 & 1,09 & 1,57 & 0,61 & 0,39 \\
& $(0,09)$ & $(0,10)$ & $(0,10)$ & $(0,11)$ & $(0,24)$ & $(0,04)$ & $(0,04)$ \\
\hline \multirow{2}{*}{7} & 0,57 & 0,19 & 0,24 & 1,24 & 1,70 & 0,62 & 0,38 \\
& $(0,05)$ & $(0,02)$ & $(0,05)$ & $(0,34)$ & $(0,41)$ & $(0,05)$ & $(0,05)$ \\
\hline \multirow{2}{*}{8} & 0,54 & 0,19 & 0,27 & 1,45 & 1,56 & 0,61 & 0,39 \\
& $(0,07)$ & $(0,04)$ & $(0,05)$ & $(0,30)$ & $(0,27)$ & $(0,04)$ & $(0,04)$ \\
\hline \multirow{2}{*}{9} & 0,30 & 0,30 & 0,40 & 1,30 & 0,94 & 0,48 & 0,52 \\
& $(0,04)$ & $(0,02)$ & $(0,03)$ & $(0,14)$ & $(0,22)$ & $(0,07)$ & $(0,07)$ \\
\hline
\end{tabular}

Explanations: in brackets are standard deviation values of individual ratios 
The structure of vitrinite and sporinite in individual samples was characterized using projection in triangular diagram $I_{1} I_{2} I_{3}$. The cluster analysis allowed to separate two groups of samples. The first group included the sporinite samples from 1 to 8 , characterized by a higher content of aliphatic than aromatic components. The system of points in the graph indicates that vitrinite is characterized by a higher relative content of aromatic than aliphatic components. Structure similar to that of vitrinite has the sporinite from sample 9 characterized by the highest coal rank and vitrinite reflectance (Fig. 5).

The similarity of the internal structures of sporinite and vitrinite is also exhibited by the loss of (qualitatively determined) fluorescence of sporinite in that sample. This is related with the process of liptinite vitrinization progressing with the coalification (Gabzdyl, 1987; Stach et al., 1982 Probierz, 1989, Pozzi \& Probierz, 1986).

The projection of the ratios $I_{1} I_{2} I_{3}$ in triangular diagram, which characterize the relative content of the basic bonds in structure of petrographic coal components, obtained based upon micro-FTIR analysis, thus allows to easily compare and characterize the chemical structure of the analyzed components.

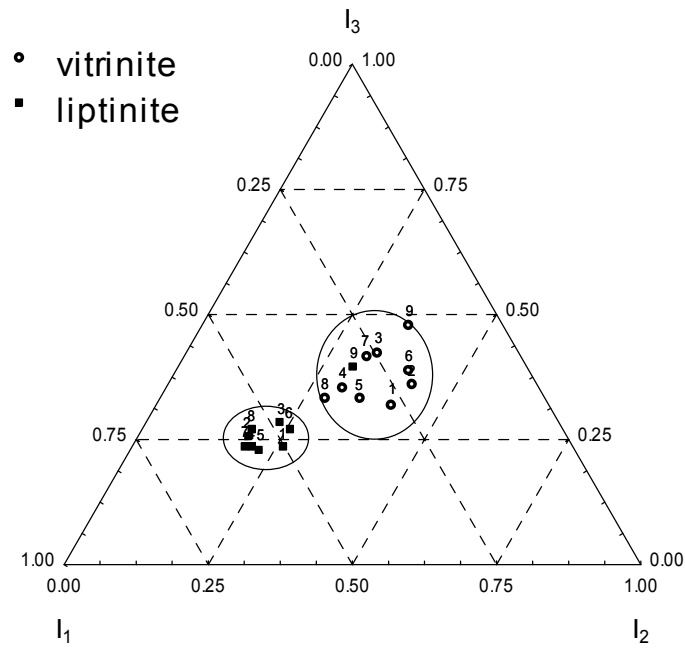

Fig. 5. Structure of vitrinite and sporinite on the triangular graph $I_{1} I_{2} I_{3}$ (Komorek, 2013a)

The ratio $I_{4}(4)$, which is the measure of the degree of aromatic ring condensation, assumes the values ranging from 0.79 to 1.35 in vitrinite. The values of this ratio obtained for liptinite are similar and vary in the range from 0.89 to 1.45 . Comparing the values of this parameter obtained for both the components and considering the standard deviation, it may be assumed that this ratio, determined for most of the analyzed samples, assumes similar values in sporinite and vitrinite (Table 3 and 4).

The structure of the aliphatic bonds in vitrinite and sporinite is characterized by the $I_{5}, I_{6}$ and $I_{7}$ ratios. The $I_{5}$ ratio (5) determined for vitrinite assumes the values from the range from 0.74 to 1.11. That same ratio, determined for sporinite, varies in the range from 0.94 to 1.70 and assumes values higher than in vitrinite in nearly all samples. Sample 9 , characterised by the highest coal 
rank and vitrinite reflectance, constitutes an exception. The ratio $I_{5}$ has similar values, in a range of the standard deviation, for vitrinite and sporinite (Table 3 and 4).

The relative content of $\mathrm{CH}_{2}$ and $\mathrm{CH}_{3}$ bonds in the sporinite and vitrinite is characterized by the ratios $I_{5}$ and $I_{6}$. The $I_{6}$ ratio (6) determined for vitrinite varies in the range from 0.42 to 0.53 . In most of the analyzed vitrinite samples it assumes values lower than 0.50 . Only in samples 1 and 6 these values are slightly higher and amount to 0.53 and 0.52 , respectively. In case of sporinite, the ratio obtained in almost all analysed samples assumes values higher than 0.50 and varies in the range from 0.55 to 0.62 . Only in sporinite from sample 9 its value is lower and amounts to 0.48 .

The $I_{7}$ ratio (7) determined for vitrinite varies in the range from 0.48 to 0.58 . In most of the analyzed vitrinite samples it has values higher than 0.50 . Only in samples 1 and 6 these values are slightly lower and amount to 0.47 and 0.48 , respectively. In sporinite, the ratio obtained for almost all analysed samples assumes values lower than 0.50 and varies in the range from 0.38 to 0.45 . Only in sporinite from sample 9 its value is higher and amounts to 0.52 (Tables 3 and 4).

The values of the $I_{5}, I_{6}$ and $I_{7}$ ratios reflect the fact that sporinite is characterized by longer and less branched aliphatic chains than vitrinite (Guo \& Bustin, 1998). The vitrinite from sample 9 , which exhibits the highest coal rank, is characterized by the shortest aliphatic chains.

The absorbance ratios determined for vitrinite have been correlated with the coal rank determined based on the $R_{v}$ vitrinite reflectance value.

Based on the research, it has been found that there is a significant correlation $(r=0.667$, $p=0.049$ ) for vitrinite in case of the $I_{3}=f\left(R_{v}\right)$ dependence. With the increase of the coal rank, the value of the $I_{3}$ ratio increases - which denotes the increase relative content of the $\mathrm{CH}_{\text {ar }}$ groups in vitrinite (Fig. 6a).

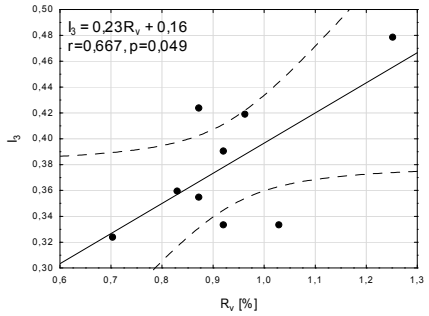

a. $I_{3}=f\left(R_{v}\right)$

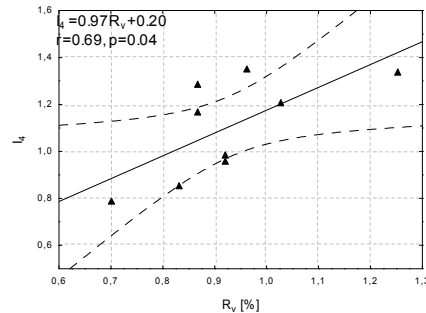

b. $I_{4}=f\left(R_{v}\right)$

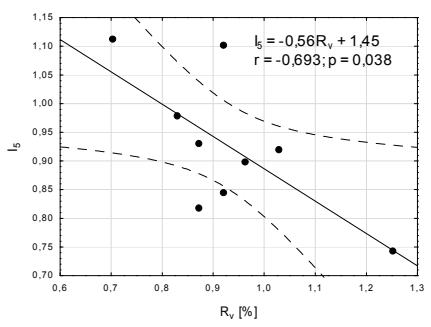

c. $I_{5}=f\left(R_{v}\right)$

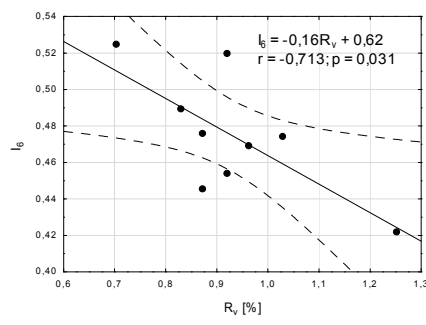

d. $I_{6}=f\left(R_{v}\right)$

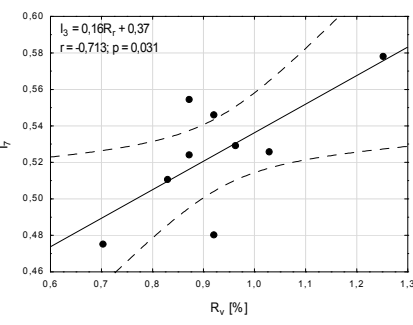

e. $I_{7}=f\left(R_{v}\right)$

Fig. 6. The relationship between ratios $I_{3}, I_{4}, I_{5}, I_{6}, I_{7}$ and coal rank determined for vitrinite (a, b Komorek 2013a) 
A similar positive correlation $(r=0.69 ; p=0.04)$ has been found in case of the $I_{4}=f\left(R_{v}\right)$ dependence, which specifies the degree of condensation of aromatic rings in vitrinite structure. According with this dependence, with increase of coal rank, the value of the $I_{4}$ ratio increases denoting the increase of the degree of condensation aromatic rings in vitrinite (Fig. 6b).

Therefore, results show that when the coal rank rises, the relative content of aromatic hydrogen functional group $\mathrm{CH}_{\mathrm{ar}}$ and condensation of vitrinite structure increase (Jasieńko, 1995).

A significant negative correlation $(r=-0.69 ; p=0.04)$ has been obtained for the $I_{5}=f\left(R_{v}\right)$ dependence. It was found that along with vitrinite reflectance increase, the value of the $I_{5}$ decreases. Along with the increase of the vitrinite reflectance in the analyzed samples, also the value of the $I_{6}$ parameter decreases $(r=-0.71, p=0.03)$. The $I_{7}$ parameter value exhibits an increase $(r=0.71, p=0.03)$ simultaneously. The obtained dependences indicate that during coalification, the aliphatic structures in vitrinite are restructured. When the coal rank rises, the aliphatic chains are getting increasingly shorter. The loss of aliphatic groups with the increase of coal rank is probably related to the reduction of the $\mathrm{CH}_{2}$ bonds (Figs. 6c-e).

The observed linear relationship between the $I_{3}, I_{4}$ and $I_{5}$ absorbance ratios and coalification expressed as the $R_{v}$ value may indicate that the aromaticity and the forms of aromatic and aliphatic structures of vitrinite can affect on the value of reflectance.

Based on the obtained results, it has been found that exist relations between individual absorbance ratios determined for vitrinite.

A significant correlation has been obtained between the $I_{3}$ and $I_{1}$ ratios. As given in the provided dependence $I_{1}=f\left(I_{3}\right)(r=-0.72 ; p=0.03)$, the content of the aliphatic components in the vitrinite structure is decreased along with the increase of the content of the $\mathrm{CH}_{\mathrm{ar}}$ aromatic groups. It may thus be asserted that the increase in vitrinite aromaticity proceeds at the cost of aliphatic components (Fig. 7a).

There are negative significant correlations in case of the $I_{2}=f\left(I_{4}\right)(r=-0.74 ; p=0.02)$ and $I_{5}=f\left(I_{4}\right)(r=-0.67 ; p=0.05)$ dependence. Simultaneously, a positive correlation it has been found in case of the $I_{3}=f\left(I_{4}\right)(r=0.71 ; p=0.03)$ dependence. It was found that with increase of degree of condensation aromatic rings, the $\mathrm{C}=\mathrm{C}$ bond content decrease, and the aliphatic chains become shorter. On the other hand, the absorption from the $\mathrm{CH}_{\mathrm{ar}}$ aromatic hydrogen functional groups increases.

It may thus be assumed that the transformation of internal structure of vitrinite during coalification undergo in the direction of the occurrence of structure characterized by higher condensation of aromatic rings. It is a consequence of the loss of aliphatic components and is concerned with the change of aromatic ring content (Fig. 7b-d).

The research results also confirm the observations conducted by Amijaya and Littke (2006) from the study of thermally metamorphosed coal with different rank. They were found that from low rank to high rank coal decrease the intensity of the $\mathrm{C}=\mathrm{C}$ band, which is assigned to aromatic ring stretching. This band is very intense in the low rank coals but relatively weak in high rank coals, which are supposed to contain more aromatic material. They concluded that the decrease absorbance $\mathrm{C}=\mathrm{C}$ bond is probably a consequence of the loss of phenolic $\mathrm{O}-\mathrm{H}$ groups with rank or change of aromatic ring content.

The obtained results thus confirm that the increase of the coal rank is not only related to the increase in the $\mathrm{C}$ element content, but also in the increase of aromaticity expressed as a ratio of aromatic hydrogen and aliphatic hydrogen content in the chemical structure of vitrinite (Amijaya \& Littke, 2006; Ward et al., 2005). 


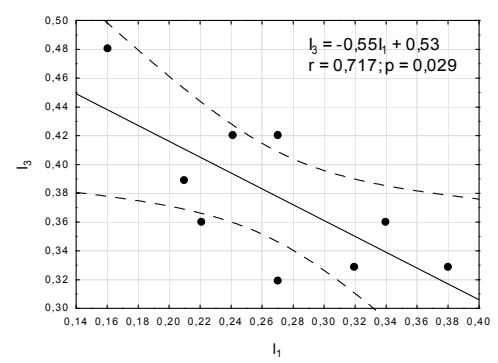

a. $I_{3}=f\left(I_{1}\right)$

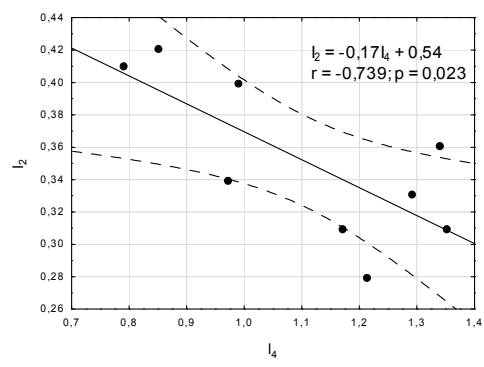

c. $I_{2}=f\left(I_{4}\right)$

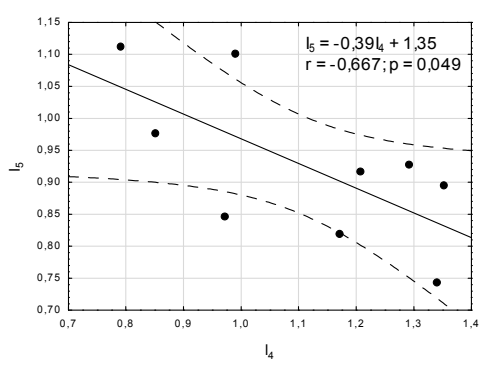

b. $I_{5}=f\left(I_{4}\right)$

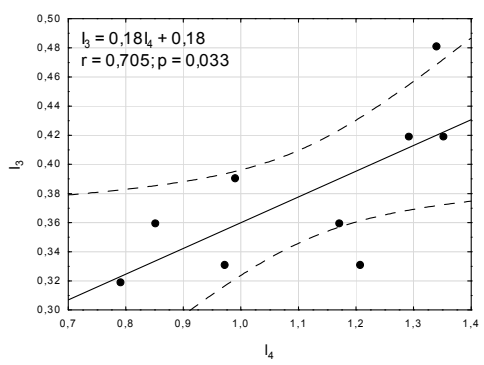

d. $I_{3}=f\left(I_{4}\right)$

Fig. 7. Relationship between absorbance ratios determined for vitrinite (a, c, d Komorek, 2013a)

The absorbance ratios determined for sporinite have been correlated with the coal rank determined based on the $R_{v}$ vitrinite reflectance value.

For liptinite, a significant correlation with coalification has been obtained for the $I_{1}=f\left(R_{v}\right)$ and $I_{3}=f\left(R_{v}\right)$ dependence. In line with the first dependence $(r=-0.672, p=0.047)$, when the coal rank increase, the value of the $I_{1}$ ratio, determining the relative content of aliphatic components in the sporinite structure, is decreased. In line with the second dependence $(r=0.788, p=0.011)$ an increase in the $I_{3}$ ratio value is observed when the coal rank rises, which denotes the increase of the $\mathrm{CH}_{\text {ar }}$ groups relative content in sporinite (Figs. 8a,b).

Similarly, stronger correlations occur between the $I_{1}(r=-0.87 ; p=0.020)$ and $I_{3}(r=0.90$; $p=0.001$ ) ratios and the $R_{1}$ reflectance of sporinite (Figs. $8 \mathrm{c}, \mathrm{d}$ ). This means that along with the increase of the coal rank, the content of the aliphatic bonds $\left(\mathrm{CH}_{2}+\mathrm{CH}_{3}\right)$ decreases in the sporinite structure, while the content of the $\mathrm{CH}_{\mathrm{ar}}$ aromatic bonds increases.

A significant correlation $(r=-0.72 ; p=0.03)$ has been obtained for the $I_{5}=f\left(R_{1}\right)$ dependence. In line with this dependence, along with the increase in sporinite reflectance, the value of the $I_{5}$ ratio is decreased. Along with the increase in sporinite reflectance, also the value of the $I_{6}$ parameter decreases in the analyzed samples $(r=-0.71, p=0.03)$. The $I_{7}$ parameter value exhibits an increase simultaneously $(r=0.71, p=0.03)$.

The found dependences indicate that during coalification the aliphatic bonds in sporinite are restructured. Along with the increase of the, coal rank the length of the aliphatic chains decreases. 


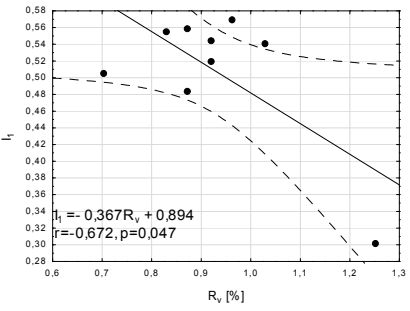

a. $I_{1}=f\left(R_{v}\right)$

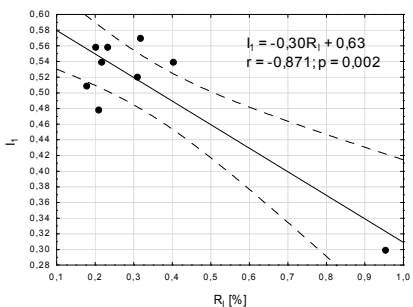

c. $I_{1}=f\left(R_{1}\right)$

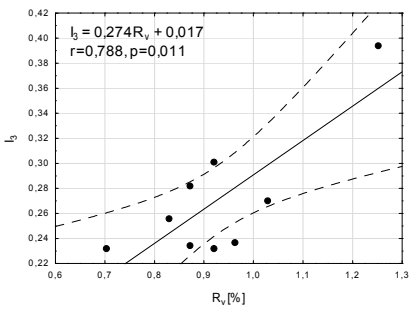

b. $I_{3}=f\left(\mathrm{R}_{\mathrm{v}}\right)$

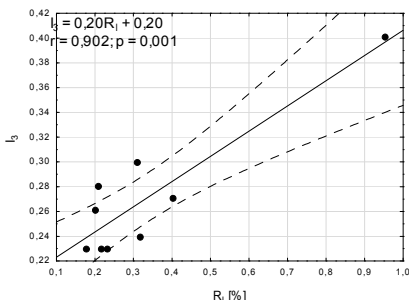

d. $I_{3}=f\left(R_{1}\right)$

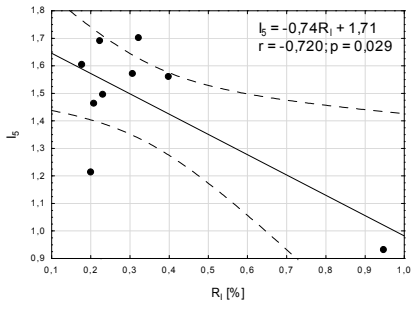

e. $I_{5}=f\left(R_{1}\right)$

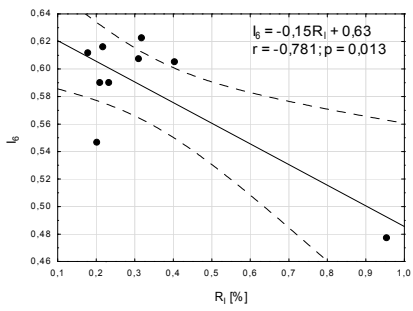

f. $I_{6}=f\left(R_{1}\right)$

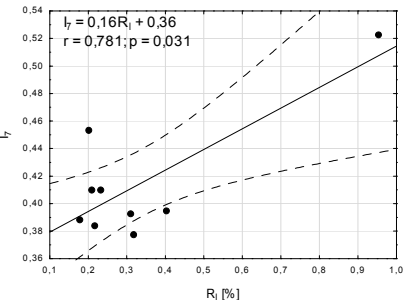

g. $I_{7}=f\left(R_{1}\right)$

Fig. 8. The relationship between ratios $I_{1}, I_{3}$ and vitrinite reflectance $R_{v}-(\mathrm{a}, \mathrm{b}) ; I_{1}, I_{3} I_{5}, I_{6} I_{7}$ and reflectance sporinite $R_{l}-$ (c-e), (a-d Komorek, 2013a)

The loss of the aliphatic bonds along with the increase of coal rank is related to the reduction of the $\mathrm{CH}_{2}$ bonds (Figs. 8 e-g).

Based on the obtained results, it has been found that exist relations between individual absorbance ratios determined for sporinite.

A significant positive correlation $(r=0.68 ; p=0.04)$ has been obtained in case of the $I_{2}=f\left(I_{3}\right)$ dependence. In line with this dependence, the content of aromatic $\mathrm{C}=\mathrm{C}$ group increase together with increase of the $\mathrm{CH}_{\mathrm{ar}}$ aromatic groups. Significant negative correlations have been obtained in case of the $I_{2}=f\left(I_{1}\right)$ and $I_{3}=f\left(I_{1}\right)$ dependences $(r=-0.77 ; p=0.02$ and $r=-0.904 ; p=0.001$, respectively). This means that when the content of aromatic hydrogen functional $\mathrm{CH}_{\mathrm{ar}}$ and $\mathrm{C}=\mathrm{C}$ aromatic groups, increases the content of aliphatic components in the structure liptinite decreases. Therefore it can be concluded that the increase in liptinite aromaticity proceeds at the cost of aliphatic components (Figs. 9 a-c). 


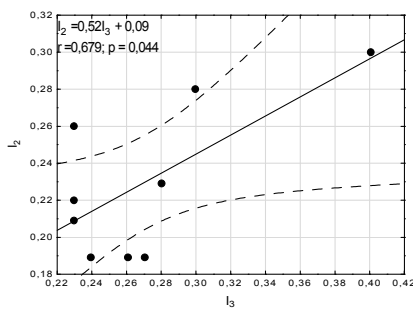

a. $I_{2}=f\left(I_{3}\right)$

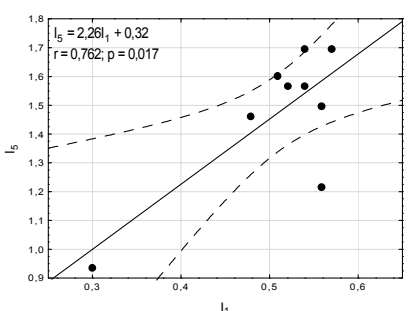

d. $I_{5}=f\left(I_{1}\right)$

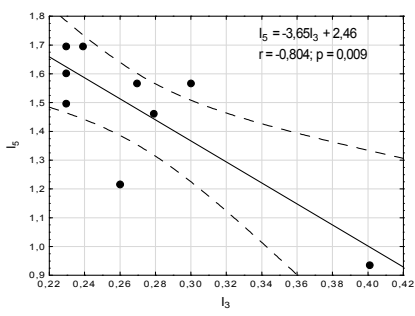

g. $I_{5}=f\left(I_{3}\right)$

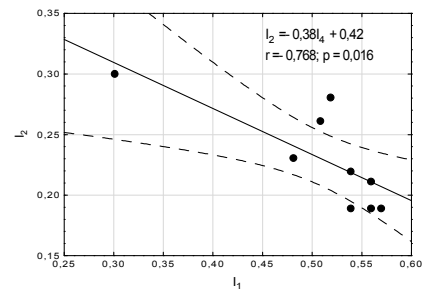

b. $I_{2}=f\left(I_{1}\right)$

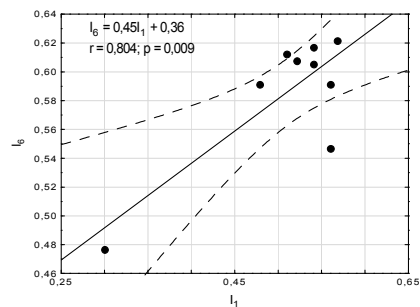

e. $I_{6}=f\left(I_{1}\right)$

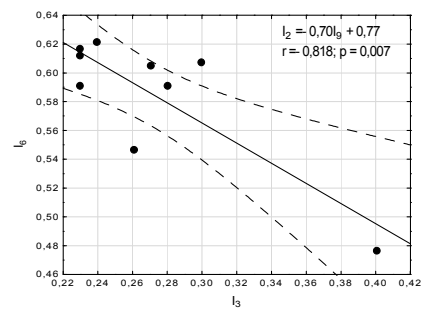

h. $I_{6}=f\left(I_{3}\right)$

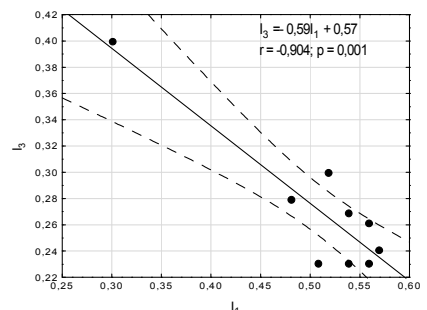

c. $I_{3}=f\left(I_{1}\right)$

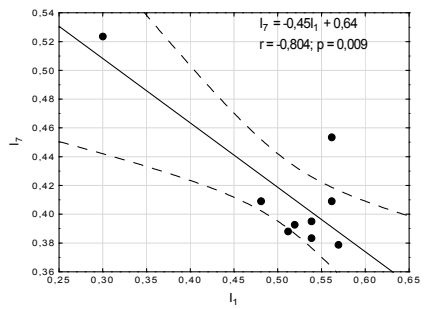

f. $I_{7}=f\left(I_{1}\right)$

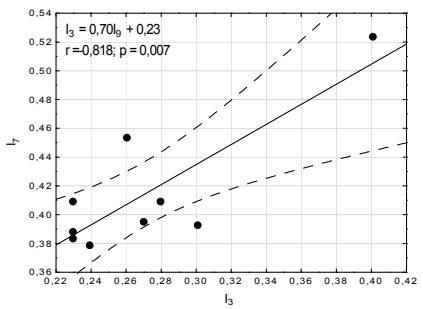

i. $I_{7}=f\left(I_{3}\right)$

Fig. 9. The relationship between absorbance ratios determined for sporinite (a-c, Komorek, 2013a)

Studies have shown that together with the loss of aliphatic groups in sporinite, characterized by $I_{1}$ ratio value, their structure is changed. The relative content of aliphatic groups characterized by the $I_{5}$ ratio is increased with the increase of the $I_{1}$ ratio $(r=0.76 ; p=0.02)$. The increase in the $I_{1}$ parameter is accompanied by the increase of the $I_{6}$ parameter $(r=0.80 ; p=0.01)$ and the decrease in the $I_{7}(r=-0.80 ; p=0.01)$ parameter. The obtained results demonstrate that with the loss of aliphatic groups in sporinite, the aliphatic chains are getting increasingly shorter. The loss of aliphatic groups with the increase of coal rank appears to be associated with amount the $\mathrm{CH}_{2}$ bonds reduction (Figs. 9d-f).

Based on the obtained results, it has also been concluded that exist a significant positive correlation between the intensity ratios of the $I_{3}$ and $I_{5}$. With the increase of the $\mathrm{CH}_{\mathrm{ar}}$ aromatic groups content, the value of the $I_{5}$ ratio in sporinite is decreased $(r=-0.80 ; p=0.01)$. At the same time, the increase of the $\mathrm{I}_{3}$ parameter in the analyzed samples is accompanied by the decrease in the $I_{6}$ parameter $(r=-0.80 ; p=0.01)$ and the increase of the $I_{7}$ parameter $(r=0.81, p=0.01)$. 
Based on the obtained results it may be concluded that the transformation of the liptinite structure into a structure characterized by a higher $\mathrm{CH}_{\mathrm{ar}}$ aromatic groups participation proceeds at the cost of $\mathrm{CH}_{2}$ aliphatic bonds (Figs. 9g-i)

The obtained results should, however, be confirmed using a larger number of samples.

\section{Conclusions}

The examined coal samples represent medium - rank orthobituminous (C) (samples 1-7) and metabituminous (B) (sample 8-9) coal (ECE-Geneva 1994).

Studies have shown that vitrinite is characterized by lower content of aliphatic components and greater content of aromatic components than sporinite. Sporinite is characterized by longer and less branched aliphatic chains than vitrinite. The shortest aliphatic chains are characteristic to the vitrinite sample 9 , which demonstrated the highest coal rank.

It was found that vitrinite is characterized by a greater relative content of aromatic than aliphatic components. The degree of condensation of aromatic rings in internal vitrinite structure increase when the coal rank rises. Also together with the loss of aliphatic groups in vitrinite, changes their structure. The aliphatic chains are getting shorter. The observed loss of aliphatic bonds with the increase of coal rank is related to the reduction of the $\mathrm{CH}_{2}$ bonds

Studies have shown that the transformation of the vitrinite internal structure towards a structure characterized by a greater degree condensation of aromatic components proceeds at the cost of restructuring the aliphatic components and is related to the restructuring of the aromatic systems.

The identified linear relationship between the $I_{3}, I_{4}$ and $I_{5}$ absorbance ratios and coal rank expressed as the $R_{v}$ value may indicate that the aromaticity and the forms of aromatic and aliphatic structures of vitrinite can affect on the value of reflectance.

The qualitative observations of the fluorescence of the sporinite from the seam 405 confirm the observations of K. Probierz made for coal coming from the SW part of the Upper Silesian Coal Basin. Sporinite from the coal samples characterized by $R_{v}$ vitrinite reflectance from $0.70 \%$ to $1.03 \%$ has exhibited clear orange fluorescence. Sporinite from the sample of coal with vitrinite reflectance $R_{v}=1.25 \%$ has exhibited almost no fluorescence (determined qualitatively) or fluoresced very weakly, similarly to other sporinites coming from the SW part of the Upper Silesian Coal Basin, described by Probierz.

The study has demonstrated, that the structure of sporinite is characterized by a greater participation of aliphatic bonds as compared to aromatic bonds. Sporinite derived from coal with the highest rank is characterized by an internal structure similar to vitrinite. This is related to the process of liptinite vitrinisation progressing with the coalification. The similarity of the internal structures of sporinite and vitrinite is also exhibited by the loss of (qualitatively determined) fluorescence of sporinite in that sample.

The relative content of the aliphatic components $\left(\mathrm{CH}_{2}+\mathrm{CH}_{3}\right)$ decreases together with increase of aromatic hydrogen functional group $\mathrm{CH}_{\mathrm{ar}}$ content in the internal structure of sporinite when the coal rank rises.

The aliphatic bonds in the sporinite are subject to changing. The aliphatic chains are getting increasingly shorter. The increase in liptinite aromaticity proceeds at the cost of aliphatic components. When the content of aromatic hydrogen functional $\mathrm{CH}_{\mathrm{ar}}$ and $\mathrm{C}=\mathrm{C}$ aromatic groups, increases the content of aliphatic components in the structure liptinite decreases. The transforma- 
tion of the liptinite structure into a structure characterized by a higher content of $\mathrm{CH}_{\mathrm{ar}}$ aromatic groups is associated with $\mathrm{CH}_{2}$ bonds reduction.

The analyses of the Polish bituminous coal using the micro-FTIR method are carried out since recently. The internal structure of vitrinite and sporinite determined using the micro-FTIR method characterizes the initial condition of the petrographic components of coal used in thermal processing. The description of the transformation of the internal structure of vitrinite and sporinite as well as other petrographic components shall allow the observation and understanding of the changes in their internal structure, occurring in the thermal processing of coal. The observation of changes in the internal structure of petrographic components - from raw coal to the product - shall allow for the control and more precise predictions of the quality of the final product.

\section{References}

Adamczyk Z., Komorek J., Lewandowska M., 2014. Specific form of coal macerals from Orzesze and Ruda beds of coal mine „Pniówek” Upper Silesian Coal Basin-Poland) as a result of thermal metamorphism. Archives of Mining Science, Vol. 59, No 1.

Amijaya H., Littke R., 2006. Properties of thermally metamorphosed coal from Tajung Enim area South Sumatra Basin, Indonesia with special reference to the coalification path of macerals. Int. Journal of Coal Geology, 66, 271-295.

Chen Y., Mastalerz M., Schimmelmann A., 2012. Characterization of chemical functional groups in macerals across different coal ranks via micro-FTIR spectroscopy. Int. Journal of Coal Geology, 104, 22-33.

Chen Y., Caro L., D., Mastalerz M., Schimelmann A., Blandon A., 2013. Mapping the chemistry of resinite, funginite and associated vitrinite in coal with micro-FTIR. Journal of Microscopy, 249, 69-81.

Gabzdyl W., 1987. Petrografia węgla. Wyd. Pol. Śl., Gliwice.

Gabzdyl W., 1999. Geologia złóż. Wyd. Pol. Śl., Gliwice.

Guo Y. Bustin R.M., 1998. Micro-FTIR spectroscopy of liptinite macerals in coal. Int. Journal of Coal Geology, 36, $259-275$.

Guo Y., Bustin R.M., 1998a. FTIR spectroscopy and reflectance of modern charcoals and fungal decayed woods: implication for studies of inertinite coals. Int. Journal of Coal Geology, 37, $29-53$.

Guo Y., Renton J.J., Penn J.H., 1996. FTIR microspectroscopy of particular liptinite- (lopinite) rich, Late Permian coals from Southern China. Int. Journal of Coal Geology, 29, 187-197.

Hacura A., Wrzalik R., Matuszewska A., 2003. Application of reflectance micro-infrared spectroscopy in coal structure studies. Anal. Bioanal. Chem., 375, 324-326.

Ibarra J.V., Muñoz E., Moliner R., 1996. FTIR study of the evolution of coal structure during the coalification process. Organic Geochemistry, 24, 6/7, 725-735.

Iglesias M.J., Jimenez A., Laggoun Defarge F., Suárez Ruiz I., 1995. FTIR study of pure vitrains and associated coals. Energy \& Fuels, 9, 458-466.

Jasieńko S., 1995. Chemia i fizyka węgla. Oficyna Wydawnicza Politechniki Wrocławskiej, Wrocław.

Komorek J., 2013. Zastosowanie analizy spektralnej w podczerwieni w mikroobszarze (mikro-FTIR) do charakterystyki struktury wewnętrznej witrynitu i liptynitu. Przegląd Górniczy, 1, 43-50.

Komorek J., 2013a. Zmiany struktury wewnętrznej witrynitu i liptynitu poddanych oddziaływaniu temperatury w zakresie 400-1200 C. Monografia. Wydawnictwo Politechniki Śląskiej, Gliwice.

Komorek J., Lewandowska M., Probierz K., 2010. Peculiarities of petrographic composition of cokink coals in southwest part Upper Silesian Coal Basin (Poland) as result of thermal metamorphism influence. Archives of Mining Science, Vol. 55, No 4, p. 783-798.

Kotas A., 1972. Ważniejsze cechy budowy geologicznej Górnośląskiego Zagłębia Węglowego na tle pozycji tektonicznej i budowy gtębokiego podtoża utworów produktywnych. Komitet Górnictwa PAN, Problemy Geodynamiki i Tapań, Tom 1, Kraków, 1-54. 
Kotas A., 1985. Uwagi o ewolucji strukturalnej Górnośląskiego Zagłębia Węglowego. U. Śl. Sosnowiec, 17-46

Lis G.P., Mastalerz M., Schimmelmann A., Lewan M.D., Stankiewicz A. B., 2005. FTIR absorption indices for thermal maturity in comparison with vitrinite reflectance $R_{o}$ in type-II kerogen from Devonian black shales. Organic Geochemistry, 36, 1533-1552.

Lu L., Sahajwalla V., Kong C. Harris D., 2001. Quantitative X-ray diffraction analysis and its application to various coals. Carbon, 39, 1821-1833.

Mastalerz M., Bustin R.M., 1993. Electron microprobe and micro-FTIR analyses applied to maceral chemistry. Int. Journal of Coal Geology, 24, 333-345.

Mastalerz M., Bustin R.M., 1995. Application of reflectance micro-Fourier transform infrared spectrometry in studying coal macerals: comparison with other Fourier transform infrared techniques. Fuel, 74, 4, 536-542.

Mastalerz M., Bustin R.M., 1996. Application of reflectance micro-Fourier transform infrared analysis to study of coal macerals: an example from the late Jurasic to early cretaceous coals of the Mist Mountains Formation, British Columbia, Canada. Int. Journal of Coal Geology, 32, 55-67.

Mastalerz M., Bustin R.M., 1997. Variation in chemistry of macerals in coals of the Mist Mountains Formation, Elk Valley coalfield, British Columbia, Canada. Int. Journal of Coal Geology, 33, 43-39.

Morga R., 2010. Zastosowanie spektroskopii FTIR i RAMANA w mikroobszarze do badań struktury wewnętrznej semifuzynitu i fuzynitu. Przegląd Górniczy, 1-2, 111-115.

Morga R., 2010a. Chemical structure of semifusinite and fusinite of steam and coking coal from the Upper Silesian Coal Basin (Poland) and its changes during heating as inferred from micro-FTIR analysis. International Journal of Coal Geology, 84, 1-15.

Morga R., 2011. Struktura chemiczna semifuzynitu i fuzynitu w węglu kamiennym z SW części GZW w świetle badań mikro-FTIR. Archives of Mining Science, Vol. 56, No 4.

Porzycki J., 1972. Seria mułowcowa piętra westfalu dolnego Górnośląskiego Zagłębia Węglowego. Prace Instytutu Geologicznego: „Karbon Górnośląskiego Zagłębia Węglowego”, Tom LXI, Wydawnictwa Geologiczne, Warszawa, 467-508

Probierz K., 1989. Wpływ metamorfizmu termalnego na stopień uwęglenia i skład petrograficzny pokładów węgla w obszarze Jastrzębia $(G Z W)$. Zeszyty Naukowe Politechniki Śląskiej, 176. Gliwice.

Probierz K., Marcisz M., Sobolewski A., 2012. Od torfu do węgli koksowych monokliny Zofiówki w obszarze Jastrzębia (południowo zachodnia część Górnośląskiego Zagłębia Węglowego). Wydawnictwo Instytutu Chemicznej Przeróbki Węgla, Zabrze.

Pozzi M., Probierz K., 1986. Zmienność zdolności odbicia światła witrynitu i sporynitu w złożu KWK „Moszczenica” (Rybnicki Okręg Węglowy). Mat. IV Konf. nt. „Petrologii węgla” AGH, Kraków, 21-24

Stach E., Mackowsky M.-Th., Teichmüller M., Taylor G.H., Chandra D., Teichmüller R., 1982. Stach 's Textbook of Coal Petrology. Gebr. Borntraeger, Berlin-Stuttgart.

Ward C.R., Li Z., Gurba L.W., 2005. Variations in coal maceral chemistry with rank advance in the German Creek and Moranbah Coal Measures of the Bowen Basin, Australia, using electron microprobe techniques. International Journal of Coal Geology, 63, 117-129.

Yule B.L., Roberts S., Marshall J.E.A., 2000. The thermal evolution of sporopollenin. Organic Geochemistry, 31, 859-870. 